\title{
Determining The Self-Regulated Learning Status Of Nursing Students Regarding Clinical Nursing Practices
}

\author{
Hemşirelik Öğrencilerinin Klinik Hemşirelik Uygulamalarına Yönelik Öz Düzenlemeli Öğrenme \\ Durumlarının Belirlenmesi
}

\section{Figen DIĞIN ${ }^{[1]}$ Gülçin İSCAN ATAŞEN ${ }^{2]}$}

Received Date:28 February

ABSTRACT

Accepted Date:22 May 2021

Self-regulated learning is an important issue to be addressed for clinical nursing practices of nursing students who will be the future healthcare workers. The objective of this descriptive study was to determine the self-regulated learning status of the nursing students regarding clinical nursing practices. The Student's Introductory Information Form and the "Self-Regulated Learning Scale for Clinical Nursing Practices (SRLSCNP)" were used in data collection. In study $76.6 \%$ of the participants were female. When the age groups of the students were evaluated, $61.7 \%$ were in the $19-21$ age range. A total of, $34.0 \%$ were 3 rd graders, and $77.0 \%$ of them had elementary family structure, and $96.8 \%$ had than 1 sibling. When the income levels of the families were evaluated, the income level of $68.1 \%$ was equal to the expenses. It was determined that nursing students had good self-regulated learning levels regarding the clinical nursing practices. It was found that the mean learning strategy score of the students was higher than the motivational sub-dimension. It was also found that the scale mean score was affected by the grade of the students and their willingness status of coming to the department. In line with these results, nursing students should be supported to improving and maintaining selfregulated learning situations.

Keywords: self-regulated learning, nursing, student

Başvuru Tarihi:28 Şubat 2021

Kabul Tarihi:22 Mayıs 2021

Öz düzenlemeli öğrenme, geleceğin sağlık çalışanları olacak hemşirelik öğrencilerinin klinik hemşirelik uygulamaları için ele alınması gereken önemli bir konudur. Tanımlayıcı nitelikte olan bu araştırmanın amacı, hemşirelik öğrencilerinin klinik hemşirelik uygulamalarına ilişkin öz düzenlemeli öğrenme durumlarını belirlemektir. Veri toplamada araştırmacılar tarafından hazırlanan öğrenci tanıtıcı bilgi formu ve "Klinik Hemşirelik Uygulamalarına Yönelik Öz Düzenlemeli Öğrenme Ölçeği” kullanıldı. Araştırmaya katılan öğrencilerin \%76,6’sını kadındır. Öğrencilerin yaş gruplarına bakıldığında \%61,7’si 19-21 yaş aralığında olduğu belirlendi, Öğrencilerin \%34,0’ünü 3.sınıf, \%77,0’si çekirdek aile yapısına sahip ve \%96,8'sinin 1 den fazla kardeşi bulunmaktadır. Ailelerin gelir düzeyine bakıldığında \%68,1'inin gelir düzeyi gider düzeyine eșittir. Araştırmada hemşirelik öğrencilerinin klinik hemşirelik uygulamalarına yönelik öz düzenlemeli öğrenme durumlarının iyi düzeyde olduğu belirlendi. Öğrencilerin öğrenme stratejisi puan ortalamasının motivasyon alt boyutuna göre daha yüksek olduğu bulundu. Ayrıca ölçek ortalama puanının öğrencilerin notlarından ve bölüme gelme istekliliklerinden etkilendiği görüldü. Bu sonuçlar doğrultusunda, hemşirelik öğrencilerinin öz düzenlemeli öğrenme durumlarını iyileștirmesi ve sürdürmesi desteklenmelidir.

Anahtar Kelimeler: öz düzenlemeli öğrenme,, hemşirelik, öğrenci nursing practices. Humanistic Perspective, 3 (2), 420-432. https://doi.org/10.47793/hp.888099

[1] Dr. | Kırklareli University | School of Health | Kırklareli | Türkiye | ORCID: 0000-0003-1861-0221 |fgndgn2013@gmail.com 


\section{INTRODUCTION}

here is a one-way information transfer in the traditional learning models. In this model, all the information required by the student is presented in a one-way manner (Kihlstrom, 2015). However, according to Albert Bandura's self-regulated learning theory, students have the ability to organize their own learning processes (Bandura, 1977). It is emphasized in today's educational understanding that the student should take an active role in his/her education. The use of student-centered learning models is preferred for lifelong learners and students who are responsible for their own learning. Self-regulation is an important part of the active learning process of students (Ilgaz \& Gul, 2014; Şenol, 2018). Taking responsibility for own behaviors of an individual, rewarding or punishing himself/herself is defined as selfregulation. In self-regulated learning, the individual controls his/her own learning (Duruhan, 2004). Self-regulated learning is an active and constructive process in which the student determines his/her own autonomy and goals of learning, controlling his/her own motivation, knowledge, and behaviors (Pintrich, 2004). Self-regulated learning provides students with awareness on their strengths and weaknesses, who, then control their motivation and satisfaction with learning (González et al., 2013).

It is expected that nursing students have high self-regulated learning ability levels to meet the increasing demands in line with rapid growth and developments in the healthcare sector (Chen et al., 2019). It is required that students who will be the nurses of the future check their own learning when they step into their professional roles. For this reason, nursing students are required to learn new skills with continuous training, transferring these skills to the clinical center with self-regulated learning (American Nurses Association, 2010); and have selfassessment and self-regulated learning skills together with professional skills (Delanie, 2018). Self-regulated learning expresses the motivational orientation and learning strategies students employ to achieve the goals expected from them (Pintrich, 1995). It is reported that nursing students must have adequate confidence and motivation to take active roles in the healthcare system. It is stated that students will acquire the required confidence and motivation with selfregulated learning (Toode, Routasalo \& Suominen, 2011); and that nursing students who have low self-regulation skills have problems in adapting to difficult tasks (Salamonson et al., 2016).

Although traditional methods are dominant in nursing education, the importance of selfregulated learning is emphasized more and more in existing nursing programs. The changes in the healthcare system, the constantly updated information, and increased complexity in clinical applications have forced nurses to continue their professional development through continuous learning methods (Sun et al., 2014; Keçeci, 2017). For this reason, the use of different teaching techniques, such as e-learning, interactive training, and student-centered education is 
recommended to improve the self-regulated learning skills of nursing students (Gaupp, Fabry \& Körner, 2018; Keçeci, 2017). Since it is difficult for nurses who are unable to direct their own learning to adapt to the changes in healthcare field, the educators in nursing need to adapt themselves to the concept of self-regulated learning (Şenol, 2018). For this reason, self-regulated learning is an important issue to be addressed for clinical nursing practices of nursing students who will be the future healthcare workers.

This study was planned to determine the self-regulated learning status of the nursing students regarding clinical nursing practices.

\section{METHOD}

\section{Study Design}

The study was planned with a descriptive design, and was conducted with nursing department students on 9-13 March 2020, at a university's health high school. A total of 336 nursing students studying at the $2^{\text {nd }}, 3^{\text {rd }}$, and $4^{\text {th }}$ grades were included in the study. The study included 235 students who were at the school on the day of the data collection and who volunteered to participate in the study as the sampling without conducting any sampling methods. Since the $1^{\text {st }}$ students did not go into clinical practice during the fall semester and because their time of clinical practice during the spring semester was not sufficient, they were excluded from the study. The participation rate was $69.9 \%$ in the study.

\section{Data collection}

The study data were collected with face-to-face interviews with students. To collect the data, verbal permission was obtained from the teachers who taught the courses, and forms were applied before the course. Verbal permission was obtained from the students who participated in the study. The data collection forms were distributed to the students, and they filled the forms on their own. The data collection forms took about 10 minutes to fill. The student information form that was prepared by the researchers in line with the literature for this study, and the "SelfRegulated Learning Scale for Clinical Nursing Practices", whose validity and reliability study for Turkish was conducted by Şenol (2018) were used in the study.

The Student Information Form. The form includes about grade, age, gender, family structure, number of siblings, income status, coming the department with his/her own wish, residence, clinical practice duration of student, distrubition of clinical practice places.

Self-Regulated Learning Scale for Clinical Nursing Practices. The scale that was used in the study was developed in 2017 by Satoko Iyama and Hitomi Maeda (Iyama \& Maeda, 2018). The Turkish validity and reliability of the scale was conducted by Şenol (2018). It was reported 
that the scale is valid and reliable for nursing students (Şenol, 2018). The scale consisted of 16 items. The sub-dimensions of the scale are two "Motivation" and "Learning Strategies". The lowest score that can be received from the scale is 16 , and the highest score is 80 . It is stated that as the score from the scale increases, the use of self-regulated learning approach of the student also increases (Şenol, 2018). The Cronbach Alpha Coefficient of the study was calculated as .85 for the total scale score in the original study; .78 for motivation sub-dimension, and .81 for the sub-dimension of learning strategies (Şenol, 2018). It was reported that the scale is valid and reliable for nursing students (Şenol, 2018). In the study the Cronbach Alpha Coefficient was calculated as .81 for the total scale score, 67 for motivation sub-dimension and .82 for for the sub-dimension of learning strategies.

\section{Data Analysis}

The data were evaluated with the SPSS 20.0 Statistics Program. Numbers, percentages, averages and standard deviation were used in the descriptive statistics. The Independent Sample t-test was used in paired group comparisons of the variables showing normal distribution, One-Way Analysis of Variance (One-Way ANOVA) was used in group comparisons with normal distribution, and Mann Whitney U-test was used with Bonferroni Correction for sub-group comparisons in variables that appeared to be significant. $\mathrm{P}<0.05$ was accepted to be significant.

\section{Ethical Considerations}

Written permission was received from the ethics committee of the university scientific research (2020/ 69456409-199-E.7326) and from the school board for the study. The students were informed that the information they gave after providing oral permission would only be used for scientific purposes, and that they could leave the study at any time.

\section{RESULTS}

The results of the descriptive characteristics of the students who participated in the study are given in Table 1.

\section{Table 1}

Descriptive Characteristics of Participant Students ( $n=235$ )

\begin{tabular}{lcc}
\hline Variables & n & $\mathbf{\%}$ \\
\hline Gender & & \\
Female & 180 & 76.6 \\
Male & 55 & 23.4 \\
\hline Age Group & & \\
$19-21$ & 145 & 61.7 \\
$22-24$ & 73 & 31.1 \\
25 and above & 17 & 7.2 \\
\hline Grade & & \\
\hline
\end{tabular}




\begin{tabular}{lcc}
\hline 2. Grade & 78 & 33.2 \\
3. Grade & 80 & 34.0 \\
4. Grade & 77 & 32.8 \\
\hline Family Structure & & \\
Elementary Family & 181 & 77.0 \\
Extended Family & 43 & 18.3 \\
Separated Family & 11 & 4.7 \\
\hline Number of Siblings & & \\
1 & 9 & 3.8 \\
2 & 73 & 31.1 \\
3 & 71 & 30.2 \\
4 and above & 82 & 34.9 \\
\hline Income Status & & \\
Income status is more than expenses & 45 & 19.1 \\
Income status equals expenses & 160 & 68.1 \\
Income status less than expenses & 30 & 12.8 \\
\hline Coming the Department With His/Her Own Wish & & \\
Yes & 183 & 77.9 \\
No & 52 & 22.1 \\
\hline Residence & & \\
With family & 22 & 9.4 \\
Dormitory/Hostel & 145 & 61.7 \\
With relatives & 4 & 1.7 \\
With friends at home & 57 & 24.3 \\
Other & 7 & 3.0 \\
\hline Clinical Practice Duration of Student & & \\
1 semester & 8 & 3.4 \\
2 semesters & 56 & 23.8 \\
3 semesters & 62 & 26.4 \\
4 semesters & 78 & 33.2 \\
5 semesters & 22 & 9.4 \\
semesters & 9 & 3.8 \\
\hline Distribution of Clinical Practice Places & & \\
Internal diseases clinics & 234 & 99.6 \\
Surgery clinics & 229 & 97.4 \\
Obstetrics and gynecology clinics & 159 & 67.7 \\
Children's health and diseases clinics & 141 & 60.0 \\
Psychological health and psychiatric disease clinics & 86 & 36.6 \\
\hline
\end{tabular}

In this respect, $76.6 \%$ of the participants were female. When the age groups of the students were evaluated, $61.7 \%$ were in the $19-21$ age range. A total of, $34.0 \%$ were 3rd graders, and $77.0 \%$ of them had elementary family structure, and $96.8 \%$ had than 1 sibling. When the income levels of the families were evaluated, the income level of $68.1 \%$ was equal to the expenses. In the study, $77 \%$ of the students came to the department voluntarily. When where the students lived was evaluated, $61.7 \%$ lived in dormitories or hostels. When the clinical practice durations of the students were evaluated, $83.4 \%$ of the students practiced clinically in the 2-4-year interval. When clinical practice locations were examined, 99.6\% performed their applications in internal diseases clinics. When clinical practice duration of student was evaluated, $33 \%$ of them have applied clinical practice for 4 semesters (Table 1 ). 
Table 2 shows the mean scores students received from the Self-Regulated Learning Scale and its sub-dimensions for Clinical Nursing Practices.

\section{Table 2}

Mean Scores in Self-Regulated Learning Scale and Sub-Dimensions on Clinical Nursing Practices $(n=235)$

\begin{tabular}{lcccc}
\hline & Min & Max & X ( $\mathbf{S S D})$ & Cronbach's Alpha \\
\hline Motivation & 11 & 35 & $26.64( \pm 3.96)$ & 0.675 \\
Learning Strategies & 20 & 45 & $36.71( \pm 4.31)$ & 0.820 \\
Total & 35 & 80 & $63.35( \pm 7.03)$ & 0.815 \\
\hline
\end{tabular}

Students received the lowest 35 and the highest 80 from the Self-Regulated Learning Scale for Clinical Nursing Practices. The mean scale score was $63.35( \pm 7.03)$. When the mean sub-dimension scores were evaluated, it was seen that the highest mean score was in Learning Strategies sub-dimension (Table 2).

Table 3 shows the comparison of the mean Self-Regulated Learning Scale scores for Clinical Nursing Practices according to the introductive characteristics of the students.

\section{Table 3}

Comparison of Mean Scores of the Students in Self-Regulated Learning Scale Regarding Clinical Nursing Practices according to Their Descriptive Characteristics ( $n=235$ )

\begin{tabular}{lcc}
\hline Characteristics & $\mathbf{X}( \pm \mathbf{S D})$ & Test value and $\mathbf{p}$ \\
\hline Gender & & \\
Female & $63.76( \pm 6.89)$ & $\mathrm{t}=1.619$ \\
Male & $62.01( \pm 7.39)$ & 0.107 \\
\hline Coming to the Department Willingly & & \\
Yes & $64.16( \pm 6.50)$ & $\mathrm{t}=3.369$ \\
No & $60.5( \pm 8.09)$ & $\mathbf{0 . 0 0 1}$ \\
\hline Grade & $62.56( \pm 7.69)$ & $\mathrm{F}=4.130$ \\
2. Grade & $65.16( \pm 6.20)$ & $\mathbf{0 . 0 1 7}$ \\
3. Grade & $62.28( \pm 6.86)$ & \\
4. Grade & & \\
\hline Age & $63.28( \pm 7.19)$ & $\mathrm{F}=0.503$ \\
19-21 & $64.08( \pm 6.43)$ & 0.225 \\
22-24 & $30.82( \pm 7.93)$ & \\
\hline Clinical Practice Duration of Student & & \\
2 years & $63.14( \pm 7.74)$ & \\
3 years & $64.69( \pm 6.66)$ & $\mathrm{F}=1.704$ \\
4 years & $62.14( \pm 6.50)$ & 0.167 \\
\hline years and above & $64.19( \pm 7.28)$ & \\
\hline
\end{tabular}

No statistically significant differences were detected between the mean scale scores based on the gender of the students $(\mathrm{p}<0.05)$. In the study, mean scale scores of students who coming to the department willingly was statistically significant higher than the others $(p<0.05)$. 
When the grades of the students were evaluated, statistically significant differences were detected between the mean scale score according to the grades $(\mathrm{p}<0.05)$. It was found that the difference stemmed from the mean scale scores of the students in the 4 th grade. The average scale score of 4 th grade nursing students was lower than the 2nd and 3rd grades. No statistically significant differences were found between the mean scale scores based on the age groups of the students and the duration of clinical practice $(\mathrm{p}<0.05)($ Table 3$)$

\section{DISCUSSION}

This study showed the results regarding the self-regulated learning status of $2^{\text {nd }}$, $3^{\text {rd }}$, and $4^{\text {th }}$ grade nursing students for clinical nursing practices.

It was determined in the study that the mean self-regulated learning scale scores of nursing students in clinical nursing practices were above the average. Similarly, Chen et al. found in their study that nursing students had high levels of self-regulated learning status (Chen et al, 2019). Another study found that techniques such as explanation, summarizing, analogy creation, and note-taking were the most frequently used learning strategies of students by establishing internal links between new and previous information (Keçeci, 2017). In the study conducted by Sağırlı and Azapağası (2009), it was found that students preferred learning strategies included meta-cognitive self-regulated learning (Sağırlı \& Azapağası, 2009). It is considered that this might have been caused by the changes in the healthcare system, increased complexity in clinical applications, and the fact that nursing students improve themselves and direct their own learning so that they do not face challenges.

In the study, considering the number of items, it is seen that the averages of the students are similarly above the average in learning strategies and motivation sub-dimensions.

A similar study reported that $3^{\text {rd }}$ grade nursing students were highly motivated (Keçeci, 2017). It is emphasized in the literature that motivation is the basis of self-regulation; and it is also stated that highly motivated students can continue their self-regulated learning by accepting their responsibilities (Vavrova et al., 2012). Another study emphasized that motivation is very effective in establishing and maintaining desired behaviors in self-regulated learning (Zumbrunn et al., 2011). For this reason, the motivations of students should be increased in the development of self-regulated learning status.

A statistically significant difference was detected between the mean scale scores based on the willingness of the students to choose their departments. In a study conducted with health education students, it was found that students who loved their schools used different learning strategies more frequently, including self-regulated learning. In the same study, significant differences were detected between self-regulated learning status of students who loved school 
and those who did not (Keçeci, 2017). There were not many sources in the literature regarding this finding; however, the fact that individuals control, observe and choose the department they want by making preferences according to their standards is the basis of self-regulated learning. For this reason, it was considered that the mean scale scores of the students who preferred the nursing department willingly were higher.

When the grades in which the students were at were evaluated, it was determined that the average scale score of $4^{\text {th }}$ grade nursing students was lower than the other grades. In a study that was conducted with nursing students, it was reported that the academic motivation levels of the students were lower than in other grades (Karabulut et al., 2015). In the study conducted by Keçeci (2017), it was also found that $3^{\text {rd }}$ grade nursing students used different learning strategies more frequently (Keçeci, 2017). It was estimated that this finding might have been caused by the anxiety of the exam that $4^{\text {th }}$ graders have to take after graduation so that they can start work as civil servants. According to the study results, senior-grade nursing students should be supported to improve their self-regulated learning status.

\section{Study Strength}

The limited number of studies on the determination of self-regulated learning situations of nursing students constitute the strength of the study.

\section{Limitations}

The limitations of the study are to be conducted with a limited number of nursing students of a university and in a single center. The results of study cannot be generalized to the universe.

\section{Conclusions and Recommendations}

It was found in the study that nursing students had good self-regulated learning status regarding clinical nursing practices. It was also determined that students' learning strategy scores were higher than the motivational sub-dimension scores, and students who came to school voluntarily had better self-regulated learning status. Also, students' self-regulated learning status decreased when they were at final grade. In line with these results, nursing students should be supported to improving and maintaining self-regulated learning situations. Nursing students' motivations should be increased to develop self-regulated learning status. However, it is also recommended that students be supported to improve self-regulated learning by identifying internal and external motivational sources, which will increase self-regulated learning status when they are at final year. In pandemic processes, such as Covid-19, which brings with it mandatory restrictions on clinical practice trainings, it is recommended to make plans to support self-regulated learning in the education of students. 


\section{Acknowledgement}

We would like to thank the participant nursing students.

\section{Conflict of interest}

The authors declared no conflict of interest.

\section{Funding}

This research did not receive any specific grant from funding agencies in the public, commercial, or not-for-profit sectors.

\section{REFERENCES}

American Nurses Association. (2010). Nursing: Scope and standards of practice. 2nd Edition. Silver Spring. MD: Nursesbooks.org.

Bandura, A. (1977). Social learning theory. Englewood Cliffs. Prentice Hall.

Chen, J. H., Björkman, A., Zou, J. H., \& Engström, M. (2019). Self-regulated learning ability, metacognitive ability, and general self-efficacy in a sample of nursing students: A crosssectional and correlational study. Nurse Education in Practice, 37, 15-21. https://doi.org/10.1016/j.nepr.2019.04.014

Delanie, C. (2018). Nursing skill achievement [Doctoral dissertation]. College of Saint Mary.

Duruhan, K. Türkiye'de okulda geleneksel anlayış ve yöntemlerle insan yetiştirmenin olumsuz etkileri. XIII. Ulusal Eğitim Bilimleri Kurultayı. 2004 [cited 2017 Dec 28]. p. 113. https://www.pegem.net/dosyalar/dokuman/125.pdf

Gaupp, R., Fabry, G., \& Körner, M. (2018). Self-regulated learning and critical reflection in an elearning on patient safety for third-year medical students. International Journal of Medical Education, 9, 189-194. https://doi.org/10.5116/ijme.5b39.d5a8

González, H. C., Carbonero, M. M. Á., Lara, O. F., \& Martín, V. P. (2013). "Learning to learn” in nursing higher education. Investigación y Educación en Enfermería, 31(3), 473- 479.

Ilgaz, G., \& Gül, A. (2014). İlköğretim ikinci kademe öğrencilerinin fen ve teknoloji dersi öz düzenlemeli öğrenme stratejilerinin incelenmesi. Ondokuz Mayıs University Journal of Education Faculty, 33(1), 261-87. https://doi.org/10.7822/egt207

Iyama, S., \& Maeda, H. (2018). Development of the self-regulated learning scale in clinical nursing practice for nursing students: consideration of its reliability and validity. Japan Journal of Nursing Science, 15(3), 226-36. https://doi.org/10.1111/jjns.12191

Karabulut, N., Yaman Aktaş, Y., \& Küçük Alemdar, D. (2015). The relationship of clinical learning environment to nursing students' academic motivation. Kontakt, 17(1), e6- e12. https://doi.org/10.1016/j.kontakt.2015.01.003

Keçeci, A. (2017). Self-regulated learning in nursing: A study from a health education course. Journal of Human Sciences, 14(4), 3830-42. https://doi.org/10.14687/jhs.v14i4.4415

Kihlstrom, J. (2015). How students learn and how we can help them. Department of Psychology, University of California, Berkley. http://socrates.berkeley.edu/ kihlstrm/GSI_2011.htm

Pintrich, P. A. (2004). Conceptual framenwork for assessing motivation and self-regulated learning in college students. Educational Psychology Review, 16(4), 385- 407. 
Pintrich, P.R. (1995). Understanding self-regulated learning. New Directions for Teaching and Learning, 63, 3-12. https://doi.org/10.1002/tl.37219956304

Sağırlı, M.Ö., \& Azapağasi, E. (2009). Investigation of self - regulated learning disabilities of college students. Ankara University Journal of Faculty of Educational Sciences, 42(2), 129 161. https://doi.org/10.1501/Egifak_0000001180

Salamonson, Y., Ramjan, L. M., van den Nieuwenhuizen, S., Metcalfe, L., Chang, S., \& Everett, B. (2016). Sense of coherence, self-regulated learning and academic performance in first year nursing students: A cluster analysis approach. Nurse Education in Practice, 17, 208213. https://doi.org/10.1016/j.nepr.2016.01.001

Şenol, A. (2018). The Investigation of the validity and reliability of the self-regulated learning scale in clinical nursing practice [Unpublished master's dissertation]. Ege University.

Sun, J.H., Liu, J.E., Wu, Y., \& Li, S.J. (2014). The effects of the student-centered clinical nursing practice mode based on the action research for clinical practicum of undergraduate students in Beijing, China. Procedia-Social and Behavioral Sciences, 141, 839-45. https://doi.org/10.1016/j.sbspro.2014.05.146

Get rights and content Toode, K., Routasalo, P., \& Suominen, T. (2011). Work motivation of nurses: A literature review. International Journal of Nursing Studies, 48(2), 246-257. https://doi.org/10.1016/j.ijnurstu.2010.09.013

Vavrova, S., Hladik, J., \& Hrbackova, K. (2012). The determinants of self-regulated learning development in students of helping professions. Procedia-Social and Behavioral Sciences, 69 (1), 332-340. https://doi.org/doi:10.1016/j.sbspro.2012.11.418

Zumbrunn, S., Tadlock, J., \& Roberts, E-D. (2011). Encouraging Self -Regulated Learning in the Classroom: A Review of the Literature Metropolitan Educational Research Consortium (MERC). Virginia Commonwealth University. 


\section{GENIŞLETILMIŞ ÖZET}

\section{Giriş}

Günümüz eğitim anlayışı içinde öğrencinin de kendi eğitimine aktif olarak rol alması gerektiği vurgulanmaktadır. Yaşam boyu öğrenen ve kendi öğrenmesinden sorumlu olan öğrenciler için öğrenci merkezli öğrenme modellerinin kullanımı tercih edilmektedir. Öz düzenleme öğrencilerin aktif öğrenme sürecinin önemli bir parçasıdır. Bireyin kendi davranışlarının sorumluluğunu alarak, kendini ödüllendirmesi ya da cezalandırması öz düzenleme olarak tanımlanmaktadır. Öz düzenlemeli öğrenmede, kişi kendi öğrenmelerini kendisi kontrol etmektedir. Öz düzenlemeli öğrenme öğrencinin kendi otonomisi ile öğrenme hedeflerini belirlediği, kendi motivasyon, bilgi ve davranışlarını kontrol ettikleri aktif ve yapıcı bir süreçtir. Geleceğin hemşiresi olacak öğrencilerin mesleki rollerine adım atarken kendi öğrenmelerini kontrol etmeleri istenmektedir. Bu nedenle öğrenci hemşirelerin sürekli eğitim yoluyla yeni beceriler öğrenmeleri ve bu öğrendikleri becerileri öz düzenlemeli öğrenme yöntemiyle klinik ortama aktarmaları gerekmektedir. Öz düzenlemeli öğrenme öğrencilerin kendilerinden beklenen hedeflere ulaşmada kullandıkları motivasyonel yönelimleri ve öğrenme stratejilerini ifade etmektedir. Öz düzenleme becerisi düşük olan öğrenci hemşirelerin zorlu görevlere uyum sağlamada sorun yaşadıkları belirtilmektedir.

Hemşirelik eğitiminde geleneksel yöntemler ağırlıklı olsa da, mevcut hemşirelik programlarında öz düzenlemeli öğrenmenin önemi daha çok vurgulanmaktadır. Sağlık bakım sistemindeki değişiklikler, bilgilerin sürekli güncellenmesi ve klinik uygulamalardaki karmaşıklığın artması, hemşirelerin sürekli öğrenme yöntemleriyle mesleki gelişimlerini devam ettirmelerini zorunlu kılmıştır. Bu nedenle hemşirelik öğrencilerinin öz düzenlemeli öğrenme becerilerinin geliştirilmesi için e-öğrenme, interaktif eğitim ve öğrenci merkezli eğitim gibi farklı öğretim tekniklerinin kullanılması önerilmektedir. Kendi öğrenmelerini yönlendiremeyen hemşirelerin sağlık alanındaki değişikliklere adapte olmaları güç olduğundan, hemşire eğitimcilerinin de kendilerini öz düzenlemeli öğrenme kavramına alıştırmaları gerekmektedir. $\mathrm{Bu}$ nedenle, geleceğin sağlık çalışanı olacak hemşirelik öğrencilerinin klinik hemşirelik uygulamalarına yönelik öz düzenlemeli öğrenme durumları, ele alınması gereken önemli bir konudur. Bu çalışma hemşirelik öğrencilerinin klinik hemşirelik uygulamalarına yönelik öz düzenlemeli öğrenme durumlarının belirlenmesi amacıyla planlanmıştır.

\section{Yöntem}

Tanımlayıcı türdeki bu araştırma 9-13 Mart 2020 tarihleri arasında bir üniversitenin sağlık yüksekokulu hemşirelik bölümü öğrencileri ile yürütülmüştür. Araştırmanın evrenini 2., 3. 
ve 4. sınıflarında eğitim gören toplam 336 hemşirelik öğrencisi oluşturmuștur. Araştırmada herhangi bir örnekleme yöntemine gidilmeyerek örnekleme çalışmaya katılmaya gönüllü olan ve veri toplama gününde okulda bulunan 235 öğrenci dahil edildi. Birinci sınıf öğrencileri güz döneminde klinik uygulamaya çıkmadıklarından ve bahar dönemindeki klinik uygulamaya çıkma süreleri yeterli düzeyde olmadığından çalışma kapsamı dışında bırakılmışlardır. Araştırma verileri öğrencilerle yüz yüze görüşme yöntemiyle toplandı. Veri toplamak için derse giren hocalardan sözel izin alınarak, dersin öncesinde formlar uygulandı. Veri toplama formları öğrencilere dağıtılarak kendi kendine doldurmaları sağlandı. Bu araştırma için öğrenci tanıtıcı bilgi formu ve Şenol (2018) tarafından Türkçe geçerlik ve güvenirliği yapılan "Klinik Hemşirelik Uygulamalarına Yönelik Öz Düzenlemeli Öğrenme Ölçeği” kullanıldı. Araştırmada tanımlayıcı istatistiklerden sayı, yüzde, ortalama ve standart sapmadan yararlanıldı. Normal dağılım gösteren değişkenlerin 2 grup karşılaştırmalarında bağımsız örneklem t testi, normal dağılım gösteren 3 ve daha fazla grup karşılaştırmalarında tek yönlü varyans analizi (OneWay ANOVA), anlamlı çıkan değişkenlerde alt grup karşılaştırmaları için Bonferonni düzeltmeli Mann Whitney U testi kullanıldı. Anlamlılık düzeyi p $<0,05$ kabul edildi.

\section{Bulgular}

Araştırmaya katılan öğrencilerin \%76,6'sını kadın öğrenciler, \%23,4'ünü ise erkek öğrenciler oluşturmaktadır. Öğrencilerin yaş gruplarına bakıldığında \%61,7'si 19-21 yaş aralığında, \%34,0'ünü 3.sınıf, \%77,0'si çekirdek aile yapısına sahip ve \%96,8'sinin 1 den fazla kardeși bulunmaktadır. Ailelerin gelir düzeyine bakıldığında \%68,1'inin gelir düzeyi gider düzeyine eşittir. Öğrencilerin \%61,7'si yurtta veya pansiyonda yaşamakta ve \%77,9’u hemşirelik bölümünü kendi isteğiyle tercih etmiştir. Öğrencilerin klinik uygulama sürelerine bakıldığında \% 83,4'ü 2-4 yıl aralığında klinik uygulamaya çıkmıștır. Klinik uygulama yerleri incelendiğinde ise \%99,6'sı Dahili kliniklerde uygulamalarını gerçekleştirmiştir. Öğrenciler klinik hemşirelik uygulamalarına yönelik öz düzenlemeli öğrenme ölçeğinden en düşük 35, en yüksek 80 puan almışlardır. Ölçek puan ortalaması da 63,35 $( \pm 7,03)$ olarak bulunmuştur. Alt boyut puan ortalamalarına bakıldığında en yüksek ortalama puan öğrenme stratejileri alt boyutunda olduğu görülmektedir. Öğrencilerin cinsiyetine göre ölçek puan ortalaması arasında istatistiksel açıdan anlamlı bir fark bulunmamıştır $(p<0,05)$. Öğrencilerin hemşirelik bölümünü kendi isteği ile seçme durumuna göre ölçek puan ortalaması arasında istatistiksel olarak anlamlı bir fark bulunmuştur ( $p>0,05)$. Araştırmada 4. sınıf hemşirelik öğrencilerinin ölçek puan ortalamasının 2. ve 3. sınıflardan daha düşük olduğu görülmüștür. Öğrencilerin yaş grupları ve klinik uygulama sürelerine göre ölçek puan ortalamaları arasında istatistiksel olarak anlamlı bir fark olmadığı bulunmuştur $(\mathrm{p}<0,05)$. 


\section{Tartışma ve Sonuç}

Araştırmada hemşirelik öğrencilerin klinik hemşirelik uygulamalarına yönelik öz düzenlemeli öğrenme ölçeği puan ortalamasının iyi düzeyde olduğu belirlendi. Yapılan benzer çalışmalarda öğrencilerin öz düzenlemeli öğrenme durumlarının yüksek olduğu ve yeni bilgiler ile önceki bilgiler arasında dahili bağlantılar kurarak, açıklama, özetleme, analoji oluşturma ve not alma gibi tekniklerin öğrencilerin en sık kullandığı öğrenme yöntemleri olduğu görüldü. Araştırmada öğrencilerin ölçek alt boyut puan ortalamalarına bakıldığında öğrenme stratejileri alt boyut puan ortalamasının motivasyon alt boyutuna göre daha yüksek olduğu görülmektedir. Motivasyonu yüksek olan öğrencilerin kendi sorumluluklarını kabul ederek öz düzenlemeli öğrenmelerini sürdürebildiği belirtilmektedir. Öğrencilerin hemşirelik bölümünü kendi isteği ile seçme durumuna göre ölçek puan ortalaması arasında istatistiksel olarak anlamlı bir fark bulunmuştur. Yapılan bir çalışmada okulunu seven öğrencilerin öz düzenlemeli öğrenmenin de aralarında olduğu farklı öğrenme stratejilerini daha sık kullandığı belirlenmiştir. Öğrencilerin bulundukları sınıflara bakıldığında ise 4.sınıf hemşirelik öğrencilerinin ölçek puan ortalamasının diğer sınıflara göre düşük olduğu görülmüştür. Yapılan benzer çalışmalarda 4.sınıf öğrencilerin diğer sınıflara göre akademik motivasyonlarının düşük olduğu ve 3.sınıf hemşirelik öğrencilerinin farklı öğrenme stratejilerini daha sık kullandığı belirlenmiștir.

Araştırmada hemşirelik öğrencilerin klinik hemşirelik uygulamalarına yönelik öz düzenlemeli öğrenme durumlarının iyi düzeyde olduğu görüldü. Öğrencilerin öğrenme stratejileri puanlarının motivasyon alt boyutuna göre daha yüksek belirlenirken, okula kendi isteği ile gelen öğrencilerin öz düzenlemeli öğrenme durumlarının daha iyi olduğu görüldü. Çalışmada öğrencilerin son sınıfa geldiklerinde öz düzenlemeli öğrenme durumlarının azaldığı belirlendi. $\mathrm{Bu}$ sonuçlar doğrultusunda hemşirelik öğrencilerinin öz düzenlemeli öğrenme durumlarının geliştirilmesi ve sürdürülmesi için desteklemesi gerekmektedir. Öz düzenlemeli öğrenme durumunun geliştirilmesi için öğrencilerin motivasyonları arttırılmalıdır. Bununla birlikte son sınıfa gelince azalan öz düzenlemeli öğrenme durumunu arttırmayı sağlayacak iç ve dış motivasyon kaynakları belirlenerek, öğrencilerin öz düzenlemeli öğrenmenin geliştirilmesi için desteklenmesi önerilmektedir. 